\title{
An Assessment On Madrasa Design As Symbol Of Communal Value Using Semiotic Analysis - Case Study of Rustem Pasha Madrasa
}

\author{
Alice Sabrina Ismail*, Nurul Syaheera Aziz \\ Faculty of Built Environment \& Surveying, Universiti Teknologi Malaysia, 81310 UTM Johor Bahru, Johor, Malaysia \\ *Corresponding author: b-alice@utm.my
}

Article history: Received 8 September 2017 Received in revised form: 14 September 2018 Accepted: 30 September 2018 Published online: 31 Dec. 2018

\begin{abstract}
The purpose of this paper is to propose an appropriate design solution for madrasa as a center of communal values development. This paper is vital as there are many arising issues relating to madrasa development in the present context that requires much needed attention from various parties. This is because the madrasa's utilitarian function and existence as a community center began to change once transformation occurred to civil society. This factor happened due to modernization and Western influence in the context of Islamic propagation. Past literature on madrasa development focused more on limited areas of study such as the documentation of historical ownership, management and maintenance, learning curriculum, discussion on the role of women in madrasa education, and the construction process of the madrasas. To date, none discusses on the strategies how to design the madrasa to function as a community center. This research analyses historic prominent madrasa Rustem Pasha (1547-1550) designed by the great architect Sinan during the expansion period of Ottoman empire (1453-1566) based on literature review using semiotic approach to establish the appropriate design attributes that interrelated with communal values. Findings indicate that five communal values involving transparency, propriety, modesty, gratitude and obligation are embedded in this historic madrasa built form and spatial arrangement for centuries as a form of 'sign' to convey message to the user. This established reference design approaches from this research is of benefit for designers, builders, developers and relevant authorities to build a communal type madrasa in the future.
\end{abstract}

Keywords: Madrasa; communal values; sign; semiotic; architecture

\begin{abstract}
Abstrak
Tujuan makalah ini adalah untuk mencadangkan penyelesaian reka bentuk yang bersesuaian untuk madrasah sebagai pusat pembangunan komuniti. Makalah ini penting kerana terdapat banyak isu yang timbul berkaitan dengan perkembangan madrasah dalam konteks sekarang yang memerlukan perhatian dari pelbagai pihak. Ini kerana fungsi dan kewujudan madrasah sebagai pusat komuniti mulai berubah setelah transformasi berlaku kepada masyarakat madani. Faktor ini berlaku disebabkan oleh pemodenan dan pengaruh Barat dalam konteks penyebaran Islam. Kajian ilmiah lampau mengenai pembangunan madrasah lebih tertumpu kepada dokumentasi pemilikan sejarah, pengurusan dan penyelenggaraan, kurikulum pembelajaran, perbincangan mengenai peranan wanita dalam pendidikan madrasah, dan proses pembinaan madrasah. Sehingga kini, tidak ada yang membincangkan strategi bagaimana merancang madrasa berfungsi sebagai pusat komuniti. Penyelidikan ini mengkaji bangunan madrasah yang terkenal dan bersejarah iaitu madrasah Rustem Pasha (15471550) yang direka oleh arkitek terkemuka, Sinan semasa tempoh pengembangan empayar Uthmaniyyah (1453-1566) berdasarkan kajian ilmiah dengan menggunakan pendekatan semiotik untuk mengenalpasti sifat reka bentuk bersesuaian yang berkaitan dengan nilai komuniti. Dapatan menunjukkan bahawa lima nilai komuniti iaitu ketelusan, kesusilaan, tawadhu', menghargai dan kewajiban tertanam dalam rekabentuk dan susun atur ruang madrasah bersejarah ini sebagai bentuk 'tanda' untuk menyampaikan mesej kepada pengguna. Garis panduan yang dibina dari kajian ini bermanfaat bagi pereka, pembina, pemaju dan pihak berkuasa yang berkaitan untuk membina madrasah berciri komuniti di masa depan.
\end{abstract}

Kata kunci: Madrasa; nilai kemasyarakatan; tanda; semiotik; senibina

(C) 2019 Penerbit UTM Press. All rights reserved

\subsection{INTRODUCTION}

Madrasa is defined as a place for teaching, including all forms of learning related to the propagation of the Islamic religion. This encompasses the teaching of religious and general knowledge as well as the Quran and Hadith to society (Alamsyah, 2011). Madrasa plays an important role as the centre for Islamic education and shaping of communal values where it become the source of knowledge to the surrounding community since the golden age of Islam to the current context. This is because the madrasa act as a symbol to cultivate values of fraternity and solidarity of the Islamic umma, that forges the Islamic spirit (Ismail, A.S 2014; Rasdi, M.T 2008). Nevertheless, the madrasa's utilitarian function and existence as a community centre began to change once transformation occurred to civil society. This factor occurred due to modernisation and Western influence in the context of the education and propagation of Islam. Although the madrasa had functioned as a centre of communal development in the past, it is currently becoming disengaged from communal life. Hence, its function in the modern times is only focused as a centre for Islamic education (Syed 2005; Shaikh 1997). Other than that, it is built in isolation from the surrounding community with a lavish architectural style and grand scale appearance (Rasdi, M.T 2008; Ismail A.S 2014). Hence, the objective of this research is to analyse how the madrasa architecture is able to function as a communal centre, via 
architectural style and elements appearance. The result of findings from this research can be applied to madrasa design in the future to give the best quality of life for its users. For this purpose, the paper will focus on the category of historic and prominent traditional madrasa that has significant value to Islamic communal development for centuries build during the expansion of Ottoman empire under the tutelage of Sultan Suleiman I (1494-1566) by the great architect, Sinan. This is important as the example of this particular madrasa was inspired by Rustem Pasha whom was the patron of the madrasa who served as the grand vizier of Sultan Suleiman I. This madrasa known as Rustem Pasha madrasa is reviewed to be successful in accentuating community values from the point of architectural design appearance including the use of teaching and learning methods that are practised in this respective madrasa. Before expounding on the data findings from the selected case study, the following section will explain the meaning of an Islamic community, the importance of community values and the relation between Islamic community values and madrasa architecture, and followed by explanation about the madrasa as a symbol of Islamic community values via architectural elements appearance.

\subsection{LITERATURE REVIEW}

\section{The Definition Of Islamic Community Values}

According to Schwartz (2012) values are defined as needs, beliefs and goals. Values are divided into two categories. The first category is terminal values (objectives and long term goals). The second category is instrumental values (behavioural style, social life) that is also known as moral values (Schwartz 2012; Lyons, Duxbury \& Higgins 2007). Both of these values exist in the collective organisation of human lives encompassing trivial scope such as the family to the greater context such as a society in a particular area (Schwartz 2012 ; Lyons, Duxbury \& Higgins 2007). From the Islamic perspective, values also play an important role in creating a more complete life. In Islam, these values are divided into spiritual values and ubudiyah (community) values. Nevertheless, ubudiyah (community) values is the main aspect because it will create a group of people with the same understanding and consensus to achieve a goal through a network of activities and societies that consists of organizations, federations, foundations, educational institutions and mosque congregations (Rasdi, M.T 2008; Ismail A.S 2014).

Community (ubudiyah) values are formed due to two main factors. Firstly, community values are formed when the community exists in a particular area and shares the same amenities. Secondly, community (ubudiyah) values are formed when a group of communities own and share the same understanding and views. For example, religious beliefs, gender orientation, work and culture (Haider 1996). Despite that, according to the Prophet Muhammad PBUH, to create an Islamic society that possesses good community values, it must be based on the ta'awun (mutual assistance), tanashur (mutual support) and tarahum (mutual love) concept (Haider 1996). This is important as it will help create Islamic community values such as being open, decent, moderate, respectful, responsible, neighbourly, gentle, tolerant, unity, sense of ownership, brotherhood and equality (Hafiz 2005; Hodge 2002). There are five community core elements which are locus, sharing, joint action, social ties, and diversity. Locus encompasses the idea that society as something that is situational and explanatory, having a sense of place, places of events or boundaries. Sharing means having the same interest with reference to contributing towards a sense of community. Joint action is depicted as a source of community unity and identity to energise the community. Social ties are the interpersonal ties that forms a society's base. Diversity can be defined as a discussion of social problems to solve an inequality (Christopher 2007). Therefore, it can be seen that community (ubudiyah) values are very important in the formation of an Islamic society.

\section{The Importance of Islamic Community Values}

Civil life needs to be balanced with the need for good community (ubudiyah) values. Hence, it can be summarised that there are five important values that are interrelated with the formation of Islamic community. The five ubudiyah (community) values are transparency, propriety, tawadhu' (humbleness), gratitude and obligation. These five values are closely tied to the built environment (Rasdi 2012). Community (ubudiyah) values can be translated through the built environment including architecture. This is because architecture is a living proof of social life that is capable of conveying meaning including the expression of religious belief and values that is practised by society through its physical and elemental aspects (Ardalan 1980; Halstead 2007; Ball \& Haque, 2003). In other words, architecture can be understood due to its unique aspect as it can create a structured relationship between the built form itself and the surrounding context, either at the time it was built or earlier (Ardalan 1980; Halstead, 2007; Ball \& Haque, 2003).To understand this, the next section will explain how architecture can be read and understood as a meaningful object which carries values and convey meaning to society.

\section{Architectural Elements as a 'sign' of Communal Values}

Scholars states that architecture can be read and understood as a form of sign and symbol based on structured methods known as semiotics. (Eco 1980; Erzen 2011; Ismail, A.S 2014;). The semiotic structured approach is commonly used in describing architecture as a meaningful object because architecture possesses the fundamental elemental basis that can convey meaning similar as oral or written text (Ismail, A.S 2014). In other words, architecture is viewed as a form of symbol or sign that has its own meaning in which it contains grammar and syntax to convey meaning to society (Chandler 2007). The use of symbols and signs represented by architecture is important towards the formation of the communal built environment, as architecture able to portray societal identity, behaviour pattern, feelings, thoughts, actions and beliefs system (Morton 2006). 'Signs' however, can only work when there exists a two-way communication system between the user within the concept of 'signifier' and 'signified'((Ismail, A.S 2014). This two-way communication is important to trigger meaning or give purpose to the use of signs. In this regard, sign is represented by architecture (Gottdiener 2014; Morton 2006). Since architecture can be understood as a form of analogue syntax and grammar, it can also be viewed as a code that can communicate and convey the builder's or patron's message as well as social and cultural expression to the user (Ismail, A.S 2014; Morton 2006). This code is represented by the physical manifestation of architecture's built form and spatial arrangement including detailing like aesthetical elements that can be read and translated by the user to implicitly give meaning to the user. As according to Fiske (2010), the dynamic quality of a built form like form and spatial aspects enables the translation of meaning into a non-verbal code form that allows communication between users to happen 
directly and indirectly. In this sense, the communal values can be represented through architectural built form and its design elements. Based on this understanding, both architectural elements encompassing built form and spatial arrangement will be described sequentially in the following section before elucidating on the used method to analyse the selected madrasa as case study. This explanation is important in justifying and strengthen the topic of discussion to describe how communal values like transparency, propriety, modesty, gratitude and obligation are embedded in building design and architectural elements.

\author{
The Interrelationship Between Communal Values (Transparency, Propriety, Modesty, Gratitude And Obligation) And \\ Architectural Elements
}

Transparency implies to openness, communication, and accountability (Mol 2015). As a communal value, transparency is greatly needed to be embraced by society to counter unlawful acts as it embodies honesty and open communication which encourages an individual, or an organization to be upfront and visible. According to Faris A.M \& Ahmad S.H. (2013), transparency is not just implying to the relationship between man and man, as well as human beings with its creator but also affiliation with other living creatures. There are five core values of transparency (Mol 2015). First is to produce societal organization that understands on own rights and individual obligations. Second is to preserve the needs of living together in a community, Third, respect and protect the rights of others, Fourth, live in unity and fifth able to work and accept others openly and acknowledged other beliefs and stature (Mol 2015). In other disciplines, such as in the context of management organizations, engineering, and technology, transparency is commonly understood as used. Transparency, is also used in other social contexts, and is operating in such a way that it is easy for others to see what actions are performed. However, in the study of architecture, the value of transparency may be clearly described through built form (Dovey 2014). This is because built form is more than utilitarian since architecture is the evidence of social life. Architecture is capable of conveying social and intellectual meaning including expressing the religious belief and political practice of society through its physical and visual form (Dovey 2014). Fiske (2010) adds that architecture may also be understood from another aspect, which involves the structured relationship that exists between the building with its immediate and wider surrounding environment. This is possible as architecture's aesthetic manifestation satisfies and motivates the human emotion as well as conveying values that may shaped society and its surrounding environment. Architecture's physical appearance and visual impression not only help engage the user to its content, similar to the reaction of a picture-object that engages our disposition to the world, but also allows the user to use physical senses to recognize the architectural function as a symbol or 'sign' (Habraken 2000; Fiske 2010).According to scholars, if the architectural design portrays visual interrelationship between the exterior and interior with barrier free movement without any significant building boundary lines, hence the value transparency in built form is well represented (Alrouf 2011). This is because the conceptual sense of welcoming is visibly seen not only in three dimensional form involving façade design but also in two dimensional form including the floor plan layout. According to Alrouf (2011), to demonstrate the value of transparency, built form needs to be constructed with many openings that are clear and straight into the interior without any obstacles. Alrouf (2011) and Grabar (1980) also noted that the facade is a major element in attracting users because the facade articulation reflects the function or image of the building hence provide attraction into the interior spaces. Indirectly, this facade works as a non-verbal communication that illustrates inner activity of user which may invite people into the building. This is notably important for an educational institution such as a madrasa that serves as a hub to spread religious knowledge for the community. This transparent value in nature is necessary to attract the community to be more comfortable and promote the learning of Islam in an open manner as a universal religion to be accepted by all (Azhar 2010). The scale of space and access are also important to portray the value of transparency (Grabar 1980). Built form need to have easy accessibility and possess diversity of entrances functioned for the user and the surrounding communities to enter the building. This openness or transparent concept is important, as according to scholar, communal building needs easy access at all times to avoid unfriendliness feeling and inhospitality atmosphere (Rabbat 2010). Multiple and series of large open spaces within the building compound are also essential to reflect the value of transparency in design built form (Rabbat 2010).In this sense, the inclusive or semi -private indicate spaces also can be transparent if there are suitable communal facilities provided within the area to promote frequent usage. This is important to be implemented in public buildings such as educational institutions to ensure effectiveness and optimal usage from the community (Rabbat 2010).

Propriety is defined as social or human rules that generates from moral conscience. According to Abd al-Hamīd (1996) and Gilsenan (2000), propriety is highly acknowledge in Islam because civilized, virtuous and noble behavior towards others is the most important factor in achieving success and individual progress. Propriety cannot be separated by the ethical term which comes from the teachings of good deeds, traits and behavior making. The better the ethics of a person, the better the quality of his humanity. The value of propriety not only limited to societal organizational behavior but do clearly reflected in the design of built form which interrelated with the concept of functionalism that can be traced back to the evolution of architectural history since the classic architecture during the Vitruvian triad till the modernity period. As in the words of Pugin (1841;5), 'there should be no features about a building which are not necessary for convenience, construction, or propriety'. From this understanding, the value of propriety in architecture could be applied to the form, detail and materials of building design. Each part of a building should conveniently serve its function. In this sense the architectural elements should be built according to significant order and functional in characteristic regardless any building typology. To add, scholars also noted that the location and position of the building are vital as it may attract visitor to and fro the building without any barrier or obstruction to produce functional building design (Wates 1987; Frank 2007). This is because the location and placement of buildings in a community context can affect the conduct and actions of a society (Wates 1987; Frank 2007). According to Krier (2009), the location and placement of buildings should also be strategically located at the pedestrian pathway or within the resident vicinity. This will indirectly create a neighborhood-friendly area (Krier 2009). Krier (2009) added that during the building placement, two main principles involving the selection of site and balanced distribution between the population and public facilities provided should be emphasized. Suitable building location is important to facilitate the community as an urban landmark and symbol of social identity (Krier, 2009). From the aspect of space formation, propriety values are also visible when the spatial arrangement are laid in hierarchical order with inclusive approach in character. This is important to acknowledge the co-existence of various space as an integrated entity which can be utilised by all to create an acceptable atmosphere (Schmid 2008; Lefebvre 1991). Schmid (2008) also outlines, spaces that reflect propriety values also devoid wastefulness and should be fully efficient in terms of usage regularity. 
Modesty implies to the quality of being relatively moderate, not excessive and keeping with proper limits (Rozak 2017). In Islam, the term moderate is widely practiced and synonym with the value of humility or tawadhu'. Meaning that one should consider oneself to be inferior. According to Rozak (2017), tawadhu ' is humble, calm, simple and avoiding arrogant acts, or sum'ah want to know other charitable deeds. The nature of tawadhu 'creates sense of equality, respect for others, tolerance, sense of belonging, and no exaggeration and love for justice (Rozak 2017). The benefits of tawadhu' are to create moderate attitude, to create self-esteem, controlling empowering emotions and construct friendly relations among society. There are three contributions in life based on the values of modesty or being moderate. First will cultivate morally balance individuals with honor, nobility and dignity. Second, create a more peaceful communal life and third, nurturing a harmonious environment for the umma'. Nonetheless, the perspective of modesty or being moderate not only centers to the study of human behavior relying on the relationship between individual and groups but the debate for moderate moralism can be seen in a larger scope involving the study of aesthetics and art including architecture as they obviously connected to ethics (Caroll 2017). In the study done by Caroll (2017: 73) she highlighted that 'the argument for moderate moralism begins by noting that artworks have functions or purposes including promoting aesthetic experiences, but not only that. Furthermore, it is the task of the artist to articulate or embody or implement those purposes in a manner or form that facilitates those purposes or that is adequate to or suitable or appropriate to those purposes'. In this sense, she upholds that moderate values is interelated with functionality as defined by Vitruvius as having the properties of utilitas (function or use) (Vitruvius 2003). Based on this, architecture may demonstrate the value of modesty and moderateness that corresponds respectively to utilitarian aspects (Bianco 2018). According to Rasdi (2012), in architecture, the value of modesty (tawadhu') 'is built on a scale that is proportional and does not dominate the creation of God. In other words, the scale and size of the building that emphasizes the value of tawadhu 'should be low and not beyond nature as a symbol of tawadhu' to God. Building scale need to be harmonious and balanced with the local context and make humans as a scale of reference (Rasdi 2012). From the aspect of the spatial organization, the value of tawadhu 'is depicted in a space of various functions, proportionate spatial layout and complemented by the undifferentiated detailing that did not divide the spaces as separate unit but can be experienced as one entity. This is important because moderate and functional space will affect the movement and needs of the local community (Rasdi 2012).

The term gratitude can be defined as to give, evaluate, respect and tolerate fellow human beings, accept the difference between every human being, and not infringe on other human rights. In strengthening social institution and build solidarity among individuals, the value of gratitude need to be implied since early childhood. This is important as by promoting gratitude values will shape an individual who knows how to appreciate, respect and tolerate, acknowledge differences as well as accept the uniqueness of each individual openly in democratic manner. Nevertheless, in the etymology of gratitude, the principles of coexistence and tolerance are important as bases for building mutually acceptable relationships between highly diverse communities within a larger society. Without tolerance and harmony the lasting peace of societies cannot be maintained, and loyalty for each other cannot be established. In the field of architecture, the value of gratitude and tolerance is important to be highlighted. Throughout history, architecture have represented differing values and have given rise to varying perceptions. Nonetheless, the role of producing suitable built environment with gratitude and tolerance value is much needed so that the representation of the building (idea) and the building (form) can be democratically accepted by all (Genevieve 2016). As noted by Genevieve $(2016 ; 37)$, 'tolerance is what transpires architectural transformation from off site to on site in which exists interrelationship between the lines of a drawing, to end building product created on site'. This is supported by Kenneth Frampton which also emphasised on the origin of the word, "tectonics" in his 'Studies in Tectonic Culture' which accentuates to the activity that raises building construction to an art form (Frampton 1985). In the words of Genevieve $(2016 ; 37)$, 'there are two approaches of interest that architects take to the value of tolerance which is ine the translation between drawing and building on site. The first approach to tolerance is to acknowledge the issues created by both materials and installation in designed details with the appearance of precision. The second approach to tolerance is to refuse to accept contractor or manufacturer standards and attempt to precisely control the installation and manufacture of the components of a building, either through early interfacing with a manufacturer, or by taking on the role of manufacturer or installer on a building project'. In this sense, the value of tolerance is seen critically addressed during the building design process, but however, according to Rasdi (2012), the value of tolerance or gratitude should also evidently appear in the built form design form and space itself. This can be seen when the design of the building is constructed with building materials and technology that meets the spirit of time and place (Maslucha 2001). In addition, building materials used also need to respond to local climate and cultural identity requirements and are compatible with the needs of the community which answers the utilitarian essentials (Rasdi, 2012). The created space also should portray the value of gratitude and tolerance by providing many accesses to enable the community to functionally utilize the space to meet collective communal needs (Maslucha 2001).

Obligation implies to a duty to act in a certain way. Though duties arise from various sources, all duties have a moral dimension and create expectations. In defining the term, scholars outlined that obligations arise from three sources: laws, promises and principles. This three sources nevertheless are governed by ethical standards of conduct fundamental to promote healthy social relations. Immanuel Kant and many ethicist, however holds belief that the value of obligation is uphold by strong moral principles that can be mandated by religious doctrine or derived through rational philosophical reasoning (Javadi 2007). In Islam, each and every human being has a moral obligation or responsibility to seek out and recognize al-sirat al-mustaqim (the righteous path) or objective ethical precepts (Javadi 2007). In this sense, all human beings have an affirmative individual responsibility and obligation to seek the righteous path in all aspects of daily life addressing the relationship of the individual vis-à-vis with god (Habluminallah) and (Habluminannas) means the relationship between a human with other humans and other living creatures. Based on this understanding, values like obligation also implies to the creation of the built environment and much effect the existence of architecture itself (Javadi 2007). This is seen within the Western tradition, in which there is a close relation between morality and architecture that much debated on the issue of obligation among architects as the shaper of the built environment, since Classical antiquity till the modern context (Rasdi 2012). Western philosophers like David Watkin for instance, debated on morality values by describing his term based on aesthetical obligations. In other words, he maintains that the claim of architecture to morality undermines individual imagination as well as the aesthetic value of the work carried on by artistic tradition involving dualistic tendency which is from the physical (exterior, visible, corporeal) and the intentional (interior, emotive, psychological, motivational) sides of animate objects (Watkin 2001). Rappoport (1994; 2016) relate the value of obligations by designers on the existence of architectural elements by highlighting that the designated building should take into account the sense of local community within the realm of environment- human behavior relations (EHBR). In other words, constructed buildings need to promote sense of belonging in terms of design, identity and style of construction that are balanced and harmonious with the conditions of the site 
and the environment. This include space making, arrangement and hierarchy to form social interaction and the reproduction of human behaviour within the created space. This can be achieved when there is an open interaction of the space provided maximally. In addition, multi-functional placement with a user-friendly layout will create a sense of responsibility among the public to greet and appreciate the space provided. In other words, accessible space will maximize the user's capacity and reflect the importance of space for social purposes (Rappoport 1994; 2016). This is important because circulation and space facilities are particularly attractive for educational buildings because society can interact openly between them without hindrance. Simple and clear circulation provides comfort and convenience to the public to use the space provided in the building (Rappoport 1994; 2016).

In summary, communal values can be translated and portrayed through architectural elements that include space making and built form during the design process till the end product. This is because, built form consists of code and syntax that is capable of delivering specific meaning to the user. As this study focuses on the influence of communal values in madrasa design, the next section will explain how madrasa as a center of education becomes a symbol of the formation of Islamic communal values in terms of space elements and built form. The analysis on the selected madrasa will be using semiotic as methodological approach. This research applies single case study as research strategy because single case study with embedded units enable the exploration of the selected case to be done thoroughly. This strategy also gives the researcher the ability to look at sub units that are located within a single case comprehensively (Yin, 2017). This is vital for the researcher to describe and understand the context of the scene in question so well that the phenomenon can be understandable to the reader and to produce theory in relationship to that context. This is important to determine how the madrasa built form symbolizes communal values. Indicators used to analyse the case study are building content and building expression involves form (physical dimension - scale and façade) as well as spatial organization.

In brief, the madrasa designed particularly by architect Sinan is chosen as case study because during his long career Sinān had built hundreds of buildings for Muslims community including mosques, palaces, harems, chapels, tombs, schools, almshouses, caravan serais, granaries, fountains, aqueducts, hospitals and madrasa. Of this diverse group of works, apart from his mosques, the madrasa had been the most influential and proven successful as the locus of Muslim communal development (Rabb 2013). This is because, in his madrasa design, Sinān had exerted his inventive architectural experimentation in consideration with communal and user needs. Moreover, he had designed 7 prominent madrasas and from the 7 madrasas built by Sinan (Encyclopedia Brittanica 2007), the Rustem Pasha Madrasa is chosen due to three main criteria. These criteria are determined by the i) the background of the madrasa which is firstly constructed by the influential master architect himself - Sinan, during the glory period of Islamic civilization which is during the expansion of the Ottoman empire (1453-1566) ii) the building serves for single purpose and function only as madrasa iii) the madrasa is still restored and actively utilized till present context maintaining its function as an education centre iii)the madrasa has significant value in terms of its contribution towards the communal development and city growth. To elucidate the process of analysing the madrasa as symbol of community based on the communal values indicators the next section will explained firstly on the method used for the study.

\subsection{METHODOLOGY}

According to Fiske (1990) a building as a sign or symbol symbolising meaning exists when the perception of the patron or local community values influences its construction elements. To explain how the madrasa can be a symbol to the 5 communal values stated above through the appearance of architectural element, the semiotic method will be used. According to Berger A.A (2011), semiotic history begins with two prominent figures, Ferdinand de Saussure (1857-1913) and Charles Sander Peirce (1839-1914). Both of them developed semiotic knowledge separately, but did not recognize each other. Saussure in Europe- more to language, while Peirce in the United States focuses on philosophy (Riyardi, 2003; Theo, 2005). The semiotic theory introduced by Charles Sanders Pierce differs from Ferdinand de Saussure. Pierce uphold the triadic principle in which there are 3 semiotic elemental elements - sign, object and interpretant. Peirce's semiotic theory then developed into semiology theory, in the field of architecture by Charles Jencks known as semiological theory, Giovanni K Koenig relate to 'sign as a vehicle' theory whereas Bonta highlights the theory of indicator and signal.For the benefit of this paper however, it is justified that their semiotic theory was unsuitable and did not coincide with the needs of the study although their semiotic approach was classified under the paradigmatic category of structuralism. This is because the thinkers above have an understanding of the semiotic theory which states that an interpretation of meaning depends largely on the interpretation of the interpretant. In other words, the meaning derived from a sign can vary according to the translator. In addition, the semiotic approach by Pierce, Jenks, Koenig and Bonta also require an understanding that emphasizes thought or action that has a habit with the object to be translated. In other words, to know what is contained on the sign, the translator's thinking requires an experience of the object understudied. Because this study emphasis on the consistent meaning of social values embodied in the architecture of the madrasa rather than based on user perception, the Saussure semiotic theory is more appropriate to the needs of this study based on 3 reasons as in the following i) Saussure's semiotic dyadic theory defines a sign as a system signifier ( $\mathrm{Sr}$ ) which is a reference to signified ( $\mathrm{Sd}$ ). Signified is also a mental concept to help understanding the mark better. This mental concept is one's intention to produce something and also a product to model a consistent and consistent cultural concept. Secondly, the mental concept by Saussure is important because the relationship between the signifier and the signified of a pattern matching where an understanding of the mark on the object $\mathrm{X}$ needs to mean $\mathrm{Y}$ in a structure that depends on the 'fix convention agreeable to a certain culture' since Saussure emphasizes on the 'arbitrariness of sign'. Third, the method of understanding the meaning of the definition is more consistent using the method of coding orderly through paradigmatic and syntagmatic approach.

Hence, Ferdinand de Saussure's semiotic theory is used to interpret the communal values that are embedded in the madrasa architecture (Fiske 1990). The focus of Ferdinand de Saussure's semiotics is based upon two-way communication which is the signifier and the signified. Signifier is a physical or meaningful matter (material aspect), that is of what is said and what is written or can be read. Signified is a mental representation, which are the thoughts or concept or material aspect value of language. These two represented elements portray the need for a two-sided external reality (Fiske 1990) The basic concept of Saussure's semiotic theory is as follows. (refer Figure 1) 


\begin{tabular}{|c|c|}
\hline Content & Paradigmatic (form) \\
\hline Expression & Syntagmatic (element) \\
\hline
\end{tabular}

Figure 4 Signs reading system (Gottdienier, 1995)

In short, the madrasa as a sign can be understood based on semiotic theory and based on the socio-semiotic theoretical framework model per the following Figure 5.

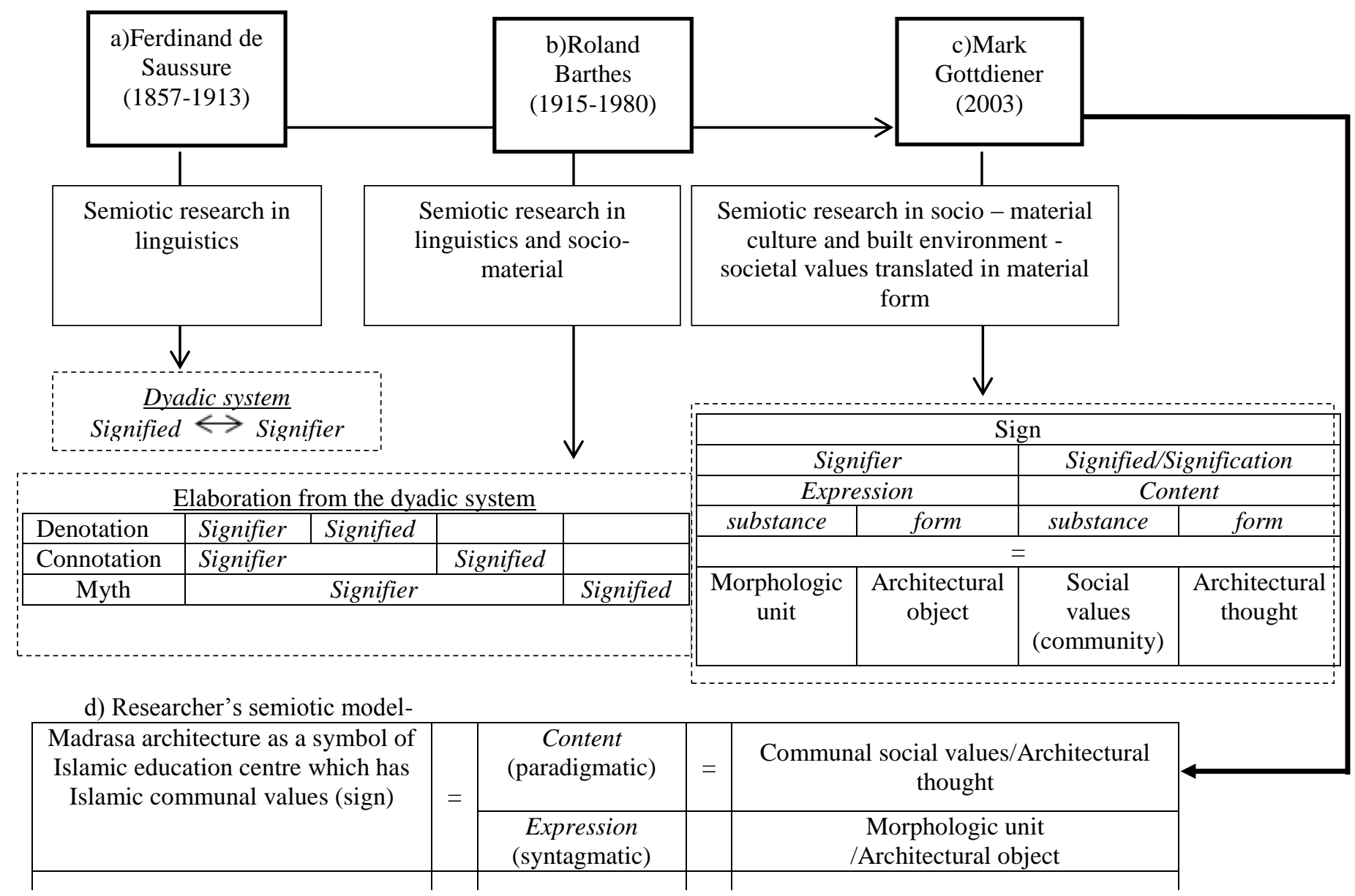

Figure 5 Semiotic model by researcher

Using the above semiotic methodology, a comprehensive data finding on the madrasa as a symbol of community values was successfully obtained. The architecture of the madrasa will be explained in depth by uncovering how the relationship with communal values are contained and reflected in the architectural elements encompassing built form and spatial aspects.

\subsection{FINDINGS}

Case study of Rustem Pasha madrasa - Historical background

The selected madrassa is located at Cagaloglu neighbourhood in Istanbul, Turkey. The madrasa was funded by Rustem Pasha by the grand vizier of Sultan Suleiman I. The madrasa took almost four years to build dated from 1547 - 1550. It was designed by Sinan whom was the chief Ottoman architect and civil engineer for Sultan Suleiman I. After completion the madrasa undergo three phases of changes in ownership and usage. The first phase occurred at the turn of the $19^{\text {th }}$ century during the fall of the Ottoman empire to secularist ideology lead by Kamal Attaturk in which the madrasa was abandoned in the year 1800 and handover to an orphanage institution. Currently, the building was restored as a place for Istanbul Foundation of Science and Culture to conduct scholar activities. Findings indicate that the madrasa is a centre of Islamic propagation and education and is able to become a symbol to symbolize the identity of the Islamic community that conveys the true Islamic community values. Based on the study of Rustem Pasha madrasa, it is clear that Sinan designed the madrasa architecture with in consideration to communal values which distinguished it as a centre of Islamic education to date. The madrasa indicates that there are communal values portrayed and symbolized in its architectural elements. The five outlined communal 
values- transparency, propriety, modesty (tawadhu'), gratitude and obligation are evidently showed in its design form and space. The madrasa is considered as a building exemplar that depicts the value of community in its architectural design which fits for the purpose as communal centre to propagate the Islamic education and teaching to the masses. Refer Table 1

Table 1 Communal values and its influence on Rustem Pasha Madrasa design

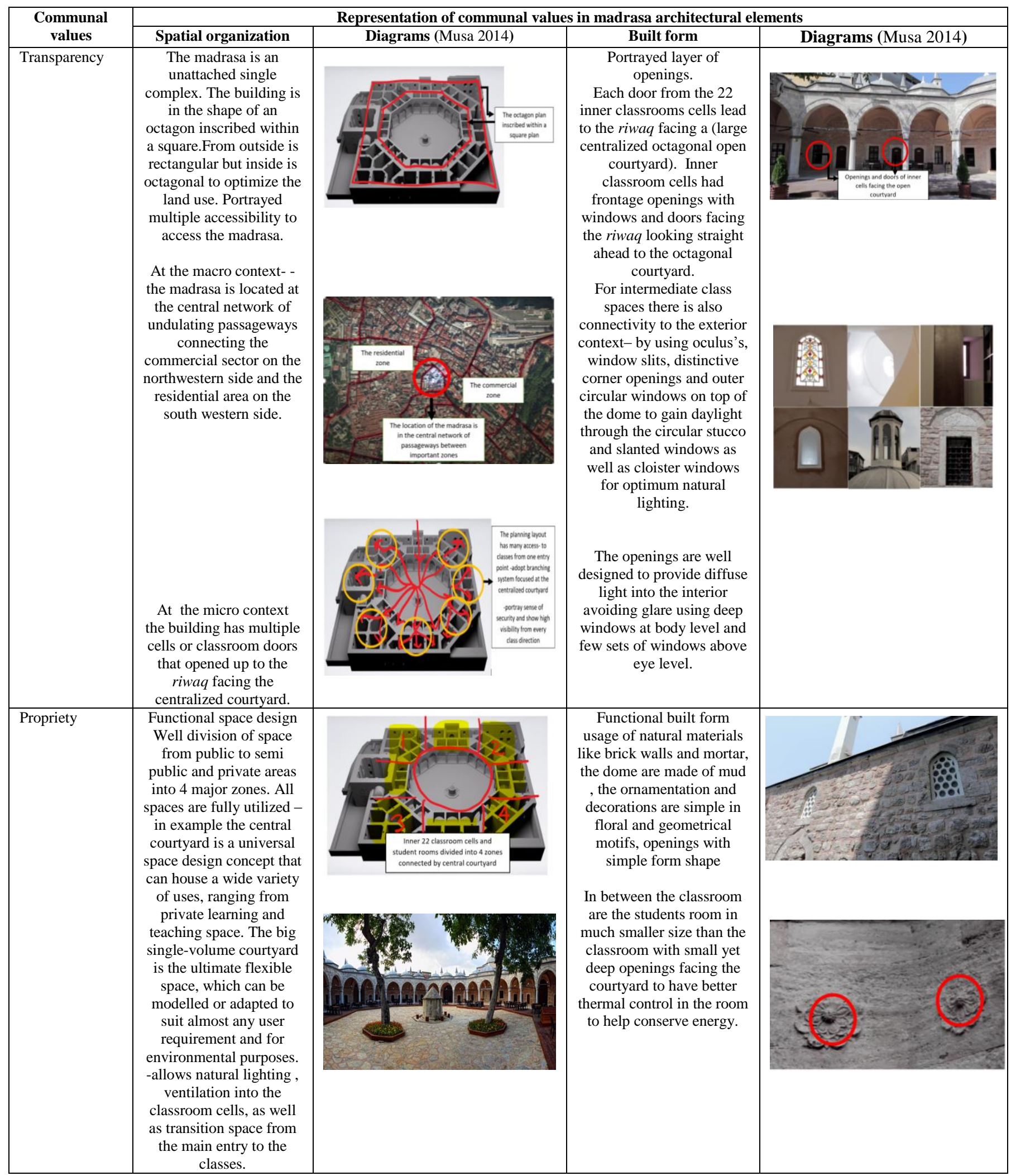




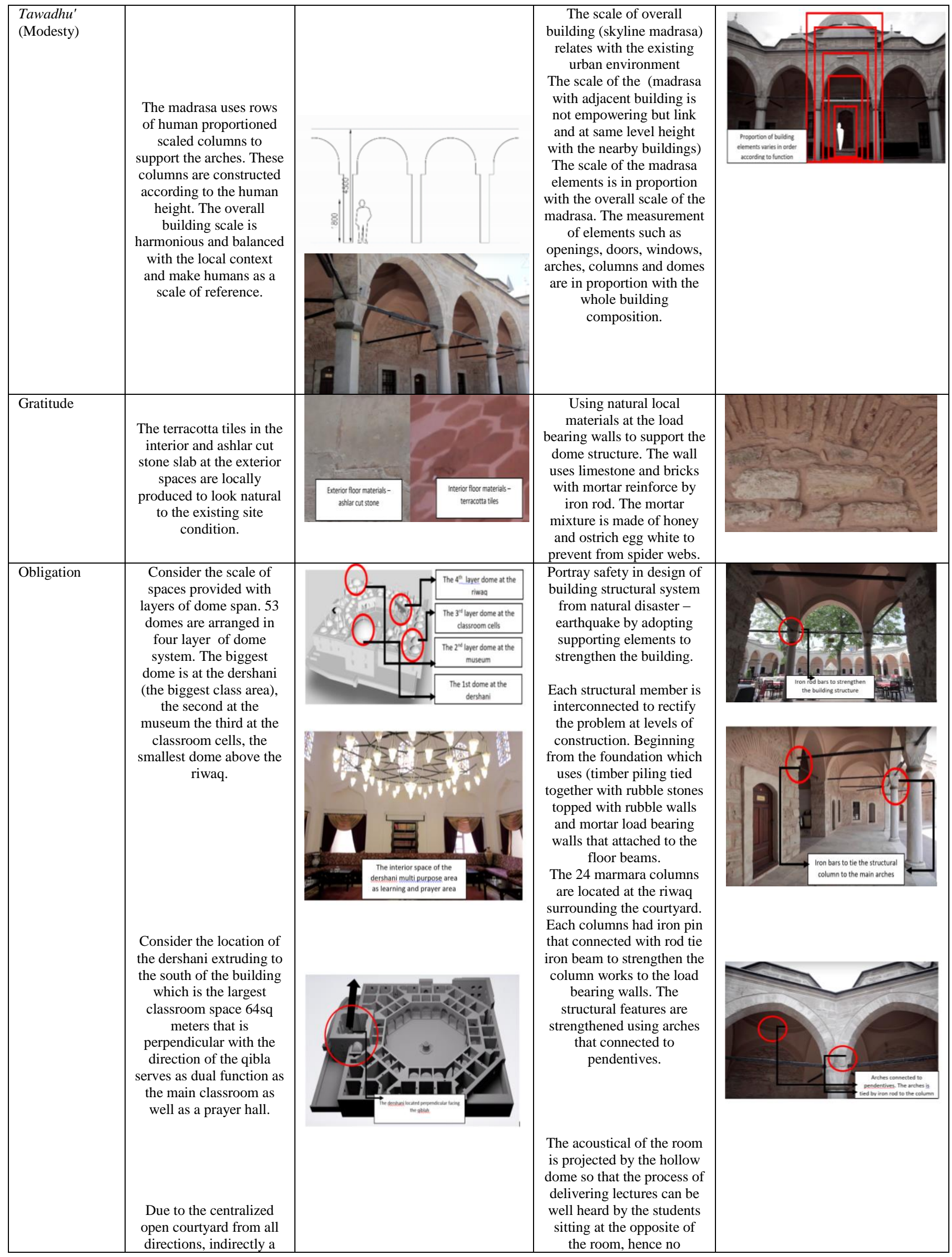




\begin{tabular}{|c|c|c|c|c|}
\hline $\begin{array}{c}\text { constant sense of } \\
\text { surveillance occurs and } \\
\text { will foster obligatory or } \\
\text { responsible values } \\
\text { among the residents and } \\
\text { surrounding community. }\end{array}$ \\
is needed.
\end{tabular}

\subsection{DISCUSSION}

From the above findings, it is proven that madrasa design capable in portraying community values through its architectural form and space to convey the Islamic values to society. Based on this the characteristic framework on madrasa design as a communal center is established. Refer Table 2.

Table 2 Architectural elements and characteristics that portray communal values

\begin{tabular}{|c|c|c|}
\hline $\begin{array}{l}\text { Community } \\
\text { values }\end{array}$ & Element & Architecture characteristic \\
\hline Transparency & $\begin{array}{ll}\text { Appropriate } & \text { location } \\
\text { and } & \text { building } \\
\text { placement } & \end{array}$ & $\begin{array}{l}\text { The placement of the madrasa need to be surrounded by local residents to attract the public. To achieve } \\
\text { this placement and setting within communal gridlines is important to promote and to spread the Islamic } \\
\text { teachings to the public. Madrasa should be clearly visible in terms of its location and to be known by the } \\
\text { Islamic and non-Islamic community. The closer the madrasa to the society, the stronger its influence, to } \\
\text { be part of the societal life in which many communal engagement activities and interrelationship can } \\
\text { occur within the madrasa ground. As a result unity and solidarity among ummah can be build and } \\
\text { strengthened. }\end{array}$ \\
\hline Propriety & $\begin{array}{l}\text { Multi-functional } \\
\text { space }\end{array}$ & $\begin{array}{l}\text { Provide provision of multi-functional or universal space design concept to accommodate the interaction } \\
\text { between madrasa user with the surrounding residents. Systematic space division need to be included } \\
\text { where the lower levels are for the community while the upper levels are for private usage. Flexible space } \\
\text { arrangements need to be introduced, in which spaces can be altered with the placement of sliding walls } \\
\text { or changeable in size, scale and height. This will encourage the optimal usage of space to enhance more } \\
\text { communal participation and engagement. }\end{array}$ \\
\hline $\begin{array}{l}\text { Tawadhu' } \\
\text { (modesty) }\end{array}$ & $\begin{array}{l}\text { Moderate design } \\
\text { appearance }\end{array}$ & $\begin{array}{l}\text { Every design and space is built with a reason and specific function. No extraneous additions should be } \\
\text { made without a specific purpose. Simple, practical, non -exclusive and moderate architecture much } \\
\text { suited and attract the community to feel at ease and at home will produce a comfortable and relax } \\
\text { environment. Moderate design approach that concerns and blend in with local identity will harmonize } \\
\text { with the existing surrounding resulting the built form to be acceptable by all. }\end{array}$ \\
\hline Obligation & $\begin{array}{l}\text { Accessible and free } \\
\text { movement }\end{array}$ & $\begin{array}{l}\text { Free movement and circulation with easy access from multiple direction will eases the movement of } \\
\text { users to enter and use the building. A centralized or branching concept is much needed. }\end{array}$ \\
\hline Gratitude & $\begin{array}{l}\text { Integrated } \\
\text { architecture }\end{array}$ & $\begin{array}{l}\text { The approach of integrated architecture involving construction materials, structure and style is vital to } \\
\text { harmonize with the local communal culture and identity. This able to strengthen the role of madrasa as } \\
\text { center of communal development. }\end{array}$ \\
\hline
\end{tabular}

\subsection{CONCLUSION}

From the above, it is clearly noted that in designing madrasa as a communal center, there are five main principles involving form and space making that contribute to the formation of five communal values (transparency, propriety, tawadhu, obligation and gratitude) in madrasa design- which are appropriate building placement, multi -functional space, moderate design appearance, accessible and free movement as well as integrated architecture. This is seen crucial as by considering the above architectural strategies, it may lead to future madrasa architecture design that functioned as a communal place rather than an exclusive institutional entity disintegrated from communal living.

\section{References}

Abd al-Hamīd, Muhsin (1996), Tajdīd al-Fikr al-Islāmī. Virginia: al- Ma‘had al'Ālamī li al-Fikr al-Islāmī.

Alamsyah, B (2011). Define the typology of Islamic Architecture Base On Hadith and Al-Quran. Jurnal Ilmiah Abdi Ilmu, 2(2), 224-238.

Alrouf, A.A. (2011). Mosque phobia: the dilemma of architecture, multiculturalism and Islam. Loonard Magazine, 1(3), 86-75.

Al-Attas, Syed Naquib. (1976). Islam the concept of religion and the foundation of ethics and morality. Kuala Lumpur: Dewan Bahasa dan Pustaka.

Ardalan N. (1980). On mosque architecture. Renata dan Darl (edited). Architecture and community, 55-56. New York: Aperture.

Assirbuny A.A.A. (2012). Malfuzat 3 hadratji. Indonesia: Pustaka Nabawi.

Azhar, Nurazmallail (2010). Persepsi Mahasiswa Terhadap Dasar Pengasingan Penginapan Mengikut Gender: Kajian Perbandingan di Universiti Teknologi 193 Malaysia (UTM), Skudai, Johor Dan Universiti Malaya, Kuala Lumpur. MyScienceWork.

Bianca, Stefano. (2005). Urban Form in the Arab World. London: Thames and Hudson.

Bianco, L. (2018). Architecture, Values And Perception: Between Rhetoric And Reality. Frontiers of Architectural Research.

Ball, C., \& Haque, A. (2003). Diversity In Religious Practice: Implications Of Islamic Values In The Public Workplace. Public Personnel Management, 32(3), 315330.

Bremner G.A.(2009). The Architecture Of The Universities Mission To Central Africa: Developing A Vernacular Tradition In The Anglican Mission Field. Journal Of The Society Of Architectural Historians, 68(4), 514-539. 
Caroll, N. (2017). Architecture, Art, And Moderate Moralism. The Nordic Journal of Aesthetics, 25(52), 68-78

Che Noraini H. and Hasan L. (2008). Islamic Religious Curriculum in Muslim Countries: The Experiences of Indonesia and Malaysia. Bulletin of Education \& Research, 30(1), 2

Ching, D.K. (2007). Architecture Form, Space And Order, 3rd edition. Hoboken, New Jersey: John Wiley \& Sons inc.

Christopher M.Blanchard. (2007). Islamic Religious Schools, Madrasas: Background. Congressional Research Service

Chandler, D. (2007). Semiotics: the basics. Routledge.

Crossland Z. (2011). Signs Of Mission: Material Semiosis And Nineteenth-Century Tswana Architecture. Signs And Society, 1(1), 79-113.

Dovey, K. (2014). Framing Places: Mediating Power In Built Form. Routledge.

Eco, U. (1980). Function and Sign: The Semiotics Of Architecture. Signs, Symbols And Architecture, 27, 356-367.

Emily R.Lai. (2011). Critical Thinking: A Literature Review. Pearson

Encyclopædia Britannica (2018), Sinan- Encyclopædia Britannica. Retrieved from https://www.britannica.com/biography/Sinan on 5/4/2017

Erzen J.N. (2011). Reading Mosques: Meaning And Architecture In Islam'. Journal Of Aesthetics And Art Criticism, 69(1), 125-131.

Ezeh C. \& Harris L.C. (2007). Servicescape research: a review and research agenda', The Marketing Review 12/2007, 7(1), 59-78.

Farish A. Noor, Yoginder Sikand \& Martin van Bruinessen. (1998). The Madrasa in Asia. Political Activism and Transnational Linkages. Amsterdam University Press.

Franck, K. A., \& Lepori, R. B. (2007). Architecture From The Inside Out: From The Body, The Senses, The Site And The Community. Academy Press.

Frampton, K. (1985). Studies in Tectonic Culture. Harvard University Graduate School of Design.

Fiske John. (1990). Introduction To Communication Studies. London: Routledge.

Genevieve Baudoin (2016), A Matter of Tolerance, The Plan Journal 1(12), 33-46, doi: 10.15274/TPJ-2016-1000

Giedion S. (1976). Space, Time And Architecture. The Growth Of A New Tradition. London: Harvard University Press Cambirdge.

Gilsenan, M. (2000). Recognizing Islam: Religion And Society In The Modern Middle East. IB Tauris.

Goodarzi. (2014). The Influence Of Sufism On The Development Of Persian Mosque Architecture. Master Thesis, Universiti Malaya.

Gottdiener, Mark. (1995). Post Modern Semiotics: Material Culture And The Forms Of Post Modern Life. U.K:Blackwell.

Gottdiener, M., Hutchison, R., \& Ryan, M. T. (2014). The New Urban Sociology. Hachette UK

Grabar O. (1980). Symbols And Sign In Islamic Architecture, Architecture And Community. Philadelphia: Aga Khan Award for Architecture, 25-32.

Habraken, N. J. (2000). The Structure Of The Ordinary: Form And Control In The Built Environment. MIT press.

Haddad, E. (2009). Charles Jencks and the historiography of Post-Modernism. The Journal Of Architecture, 14(4), 493-510.

Hafiz A, Hussin S, Azmi S.S (2005) Sistem Pembelajaran dan Kaedah Hafazan al-Quran yang Efektif : Satu Kajian di Kuala Lumpur dan Terengganu, Universiti Teknologi Malaysia.

Haider G. (1996). Faith is the Architect Reflections On The Mosque. Architecture \& Behaviour in Islamic Cultures, 11(3-4), 243-248.

Hawkes T. (2003). Structuralism and Semiotics. London \& New York: Routledge.

Halstead, J. M. (2007). Islamic values: a distinctive framework for moral education?. Journal of Moral Education, 36(3), 283-296.

Hillier \& Hanson. (2006). The social logic of space. UK: Cambridge University Press.

Hodge, D. R. (2002). Working with Muslim Youths: Understanding The Values And Beliefs Of Islamic Discourse. Children \& Schools, 24(1), 6-20.

Ismail, Alice Sabrina. (2008). The Influence Of Islamic Political Ideas On The Design Of State Mosque In Peninsular West Malaysia. PHD Dissertation. University of Queensland Technology.

Ismail, Alice Sabrina. (2010).Mosque Architecture and Political Agenda in Twentieth Century Malaysia. The Journal of Architecture, 15 (2), 137-152

Ismail, Alice Sabrina. (2014).Communal Mosques: Design Functionality Towards The Development Of Sustainability For Community. Procedia Social and Behavioral Sciences, $153,106-120$

Ismail, Alice Sabrina. (2016). Architectural Style of Dawah Mosque in Malaysia: from Vernacular to Modern Structures, International Journal of Built Environment and Sustainability, 3(2), 70-78

Javadi Amoli, A. (2007). Right and Obligation in Islam. Qom, Asra Publications

Joseph R. (1981). The Semiotic Of The Islamic Mosque. Arab Studies Quarterly, 3(3), 285-295.

Kenneth Frampton, Studies in Tectonic Culture: The Poetics of Construction in Nineteenth and Twentieth Century Architecture, ed. John Cava (Cambridge MA, USA: MIT Press, 1995), 4.

Krier L (2009). The Architecture of Community, Architecture:Choice or Fate, Papadakis, London, 1998

Lefebvre, H. (1991). The Production Of Space, translated by Donald Nicholson-Smith.

Longhurst, Christopher E.(2012). Theology of Mosque: the Sacred Inspiring Form, Function And Design in Islamic Architecture'. Leonard, Art And Architecture Magazine. Architectural Critical Review, 2(8), 3-13.

Lyons, S. T., Duxbury, L., \& Higgins, C. (2007). An Empirical Assessment Of Generational Differences In Basic Human Values. Psychological Reports, 101(2), 339352.

Manan, Rosdan \& Rasdi, M.T. (2012). Rekabentuk Senibina Barat Kurun Ke 19: Wacana Moral. Kuala Lumpur: Dewan Bahasa dan Pustaka.

Moustafa A.A. 1988. Architectural Representation And Meaning: Towards A Theory Of Interpretation. Master Of Science In Architecture Studies. The Massachusetts Institute of technology.

Mohd Roslan \& Wan Mohd Tarmidzi. (2011). Jurnal At-Ta'dib, 6(1) Juni, 59-78

Mol, A. P. (2015). Transparency and Value Chain Sustainability. Journal of Cleaner Production, 107, 154-161.

Morton, J. (2006). The Integration Of Images Into Architecture Presentations: A Semiotic Analysis. Art, Design \& Communication in Higher Education, 5(1), 21-37.

Maslucha, L. (2001). Spatial and Architectural Design Aspects in Community Based Mosques. Journal of Islamic Architecture, 2(2), 70-77

Mulhall Anne. (2003). In The Field: Notes On Observation In Qualitative Research. Methodological Issue In Nursing Research. Journal Of Advanced Nursing, 41(3), 306-313. Blackwell Publishing. Ltd.,

Musa, Muhamad Hamidullah (2014)The Masters Patrimony - Rustem Pasha Madrasa retrieved from https://www.youtube.com/watch?v=3ew6KDR3TAA

Nooraini Othman, Khairul Azmi Mohamad. (2011). Eclectic Model in the Malaysian Education System.

Nu'mani M.M. (2001). Malfuzhat siri Alif: Kata-Kata, Nasihat, Ucapan, Panduan, Petunjuk Hadrat Maulana Muhammad Ilyas rah. Kuala Lumpur: Abdul Majid b. Ahmad Ishak.

Omer, Spahic. (2010) Some Lessons from Prophet Muhammad (SAW) in Architecture: The Prophet's Mosque in Madinah. Intellectual Discourse, 18(1), 115-140.

Or F. (1985). Scale in architecture. New York: Van Nostrand Reinhold.

Ozay, M. (2011). World Journal of Islamic History and Civilization,. A Revisiting Cultural Transformation: Education System in Malaya During The Colonial Era $37-48$

Pugin, A. W. N. (1841). The True Principles of Pointed Christian Architecture.

Rabbat, N. (2010). Mamluk history through architecture: Monuments, culture and politics in medieval Egypt and Syria. IB Tauris

Rabb, P. (2013). "We are All Servants Here!" Mimar Sinan-Architect of the Ottoman Empire. Periodica Polytechnica. Architecture, $44(1), 17$.

Rapoport, A. (1994). Spatial Organization And The Built Environment. Companion Encyclopedia Of Anthropology: Humanity, Culture And Social Life, 460-502.

Rapoport, A. (2016). Human Aspects Of Urban Form: Towards A Man—Environment Approach To Urban Form And Design. Elsevier.

Rasdi, M. T. (1998). The Mosque As A Community Development Centre: Programme and Architectural Design Guidelines for contemporary Muslim Societies. Skudai: Penerbit Universiti Teknologi Malaysia.

Rasdi, M.T. (2007). Mosque Architecture In Malaysia:Classification Of Styles And Possible Influence. Journal Alam Bina, 9(3), 1-37.

Rasdi, M. T., \& Utaberta, N. (2012). The Design Of Mosques As Community Development Centers From The Perspective Of The Sunna And Wright's Organic Architecture. Journal of Islamic Architecture, 1(1)

Rasdi, M. T., \& Manan, R. A. (2012). Reka bentuk seni bina Barat kurun ke-19: Wacana Moral. Dewan Bahasa dan Pustaka 
Rudner, M. (1977). South East Asian Studies. Education, Development and Change in Malaysia, 23-62.

Rokeach. (1974).The Nature Of Human Value. Political Science Quarterly, 89(2), 399-401.

Rosnani Hashim. (1994). Educational Dualism In Malaysia: Implications For Theory And Practice. University Of Florida

Rozak, P. (2017). Indikator Tawadhu dalam Keseharian. Madaniyah, 7(1).

Shatha, Malhis.(2004). Local Identity of modern Amman-Jordan: A Perceptual Approach Towards Identifying An Inter-Subjective And Shared Architectural Schemata'. Urban Design International, 9(3), 119-130.

Shaikh Ali Mohammad Mokhtar. (1997). Peranan Masjid Dalam Islam. Yayasan dakwah Islamiah Malaysia.

Schwartz, S. H. (2012). An Overview Of The Schwartz Theory Of Basic Values. Online Readings In Psychology And Culture, $2(1), 11$.

Schmid, C. (2008). Henri Lefebvre's Theory Of The Production Of Space: Towards A Three-Dimensional Dialectic. In Space, difference, Everyday Life, 41-59. Routledge.

Syed Muhd Khairudin Aljunied, Dayang Istiaisyah Hussin. (2005). Estranged from the Ideal Past: Historical Evolution of Madrassahs in Singapore. Journal of Muslim Minority Affairs, 25.

Verkaaik O. (2012). Designing the 'Anti-Mosque': Identity, Religion And Effect In Contemporary European Mosque Design. Social Anthropology, 20(2), 161-176.

Vitruvius, \& Smith, T. G. (2003). Vitruvius On Architecture. Monacelli.

Wates, N., \& Knevitt, C. (1987). Community Architecture. How People Are Creating Their Own Environment, London: Routledge.

Watkin, D. (2001). Morality and Architecture Revisited. University of Chicago Press.

Wright, Frank Lloyd. (1908). In the cause of Architecture, Editor, Gutheim F. A.New York: Architectural Record Books.

Yin, R. K. (2017). Case Study Research And Applications: Design And Methods. Sage Publications.

Zevi, Bruno. (1957). Architecture as Space: How To Look At Architecture, Joseph a. Barry, ed. New York: Horizon Press. 